\title{
An in situ experiment to investigate the depletion of seston above an interface feeder field on the continental slope of the western Barents Sea
}

\author{
Laurenz Thomsen ${ }^{1}$, Gerhard Graf ${ }^{1}$, Karen von Juterzenka ${ }^{2}$, Ursula Witte ${ }^{1}$ \\ ${ }^{1}$ GEOMAR, Wischhofstr. 1-3, D-24148 Kiel, Germany \\ ${ }^{2}$ Institut für Polarökologie, Wischhofstr. 1-3, D-24148 Kiel, Germany
}

\begin{abstract}
During 'Meteor' Cruise 17 in July 1991, bottom water and sediment samples were taken from 3 stations on a $3.7 \mathrm{~km}$ long transect along the continental slope of the western Barents Sea between $74^{\circ} 58.3^{\prime} \mathrm{N}, 14^{\circ} 44.8^{\prime} \mathrm{E}$ and $74^{\circ} 59.8^{\prime} \mathrm{N}, 14^{\circ} 40.1^{\prime} \mathrm{E}$, across an area occupied by macrofauna feeding at the sediment-water interface at $1340 \mathrm{~m}$ water depth. Profiles of oxygen, total particulate matter, total inorganic matter, particulate organic carbon, bacterial abundance and chlorophyll equivalents were taken in the benthic boundary layer ( 10 to $40 \mathrm{~cm}$ height above the sea floor). Between the upstream and downstream stations total particulate matter and particulate organic carbon decreased by 41 and $23 \%$, respectively, at a height of between 10 and $25 \mathrm{~cm}$ above the seabed. Chlorophyll equivalents in the bottom water increased by $85 \%$, in the sediments by $56 \%$. Abundance of macrofauna showed no significant correlation to bottom water and sediment data. Compared to vertical particle fluxes, as determined from sediment trap data, particle fluxes to the sea floor were corrected by a lateral advection factor of 2 to 3.7 .
\end{abstract}

KEY WORDS: Experiment - Depletion of seston - Interface feeder - Continental slope $\cdot$ Barents Sea

\section{INTRODUCTION}

Recent attention to the ecological significance of the benthic boundary layer showed that the near-seabed region is characterized by strong vertical gradients of flow velocity and particle concentration (Jumars \& Gallagher 1982, Nowell \& Jumars 1984, Sternberg et al. 1986). In addition to vertical settling, processes laterally distributing and sorting the material falling out of the water column can be as important in determining the availability of this material as food. Benthic organisms often rely on advective sources for their food supply (LaBarbera 1984, Miller et al. 1984). They are dependent on the fluid medium for transport of this material and can in many cases influence these transport processes (Grant 1983, Eckmann \& Nowell 1984, Jumars \& Nowell 1984, Miller et al. 1984). The contribution of biodeposition to particle incorporation into the sediment has, with the exception of studies in shallow water areas (Loo \& Rosenberg 1989, Ritzrau 1990, Asmus \& Asmus 1992, Muschenheim \& Newell
1992), only been investigated in flumes (Carey 1983, Muschenheim 1987). The data base obtained from studies on feeding behaviour of many macrobenthic species (Miller et al. 1992) show that biodeposition can be more important as a food source of the benthos than material deposited by sedimentation.

The aim of this study was to investigate the depletion of seston above an area occupied by macrofauna feeding at the sediment-water interface on the continental slope of the western Barents Sea under natural conditions. One of the features that made this site particularly suitable for such an experiment is the existence of a depo-center, which is located on the continental slope at about $1400 \mathrm{~m}$ depth (Blaume 1992). Sediments in this area were covered with macrofauna of high abundance. This raised the question of whether or not a change in the composition of particles in the bottom waters is a result of a modification by interface-feeding macrofauna, which is able to switch between deposit feeding and passive suspension feeding (Taghon \& Greene 1992). 


\section{METHODS}

During 'Meteor' Cruise 17 in July 1991, samples of bottom water and sediment were taken from 3 stations on a $3.7 \mathrm{~km}$ long transect parallel to the continental slope of the western Barents Sea (Fig. 1) between $74^{\circ} 58.3^{\prime} \mathrm{N}, 14^{\circ} 44.8^{\prime} \mathrm{E}$ and $74^{\circ} 59.8^{\prime} \mathrm{N}, 14^{\circ} 40.1^{\prime} \mathrm{E}$.

Sampling. The Bioprobe system, an in situ bottom water sampler for deep-sea deployments (Thomsen et al. 1994), was used to collect $15 \mathrm{I}$ of water at heights of $10,15,25$ and $40 \mathrm{~cm}$ above the sea floor. Current velocity was measured by 2 thermistor flowmeters mounted in a vertical array at heights of 20 and $65 \mathrm{~cm}$ above the sea floor. The flow direction was determined from photographs of a Benthos deep-sea compass with a vane. After deployment at the first station, the direction of bottom currents was determined using photographs taken by a Benthos camera. Following this, the remaining stations were fixed.

Samples of the sediment surface 10 to $10 \mathrm{~cm}$ depth) were taken with a multicorer (Barnett et al. 1984) modified to attach 8 tubes of $10 \mathrm{~cm}$ in diameter. The cores were sicced in $\mathrm{i} \mathrm{cm}$ intervals down to a sediment depth of $10 \mathrm{~cm}$. Subsamples for different analyses were taken using cut-off plastic syringes. Boxcorer samples $\left(0.25 \mathrm{~m}^{2}\right)$ were taken at each station for macrofauna analyses (2 corers at Stns B and C, 1 at Stn A). Macrofauna samples of the top $30 \mathrm{~cm}$ of sediment were sieved through $500 \mu \mathrm{m}$ mesh and were preserved in borax-buffered 3\% Kohrsolin (Brey 1986). A total of 4 water samples and 4 sediment samples at each station were analyzed for the following parameters: particulate organic carbon (POC), chlorophyll equivalents, seston, and total inorganic matter (TIM). POC of water was measured with a Heraeus CHNAnalyzer. Chlorophyll equivalents were analyzed spectrofluorometrically with a Turner Fluorometer and calculated using the equations of Lorenzen (1967). Seston [total particulate matter (TPM)], and TIM were determined using the method of Bodungen et al. (1991). Bacterial numbers were determined by the Acridine
Orange epifluorescence direct counting technique of Hobbie et al. (1977) using a Zeiss 'Standard' fluorescence microscope. Oxygen was measured according to Grasshoff et al. (1976). Oxygen consumption of 3 sediment cores at Stns $A$ and $C$ was measured as described by Graf (1987), using the multiple corer tubes as microcosms. Incubation time was $36 \mathrm{~h}$. Statistics (Wilcoxon signed rank) were evaluated using the statistical software 'Stat View II' for Macintosh computers.

\section{RESULTS}

\section{Surface sediments}

Oxygen consumption of the sediment was $58 \pm$ $7 \mu \mathrm{mol} \mathrm{m} \mathrm{m}^{-2} \mathrm{~h}^{-1}$ at the upstream Stn $\mathrm{A}$ and $58 \pm 1 \mu \mathrm{mol}$ $\mathrm{m}^{-2} \mathrm{~h}^{-1}$ at the downstream Stn C (Fig. 2). Chlorophyll equivalent content in the sediments integrated over the top $10 \mathrm{~cm}$ layer increased in the direction of flow by $56 \%$ from $65.5 \mathrm{mg}$ (Stn A) to $101.9 \mathrm{mg} \mathrm{m}^{-2} 10 \mathrm{~cm}^{-1}$ (Stn C).

The macrofauna in the area was dominated by sedentary polychaetes and ophiurids. Abundance of macrofauna (infaunal polychaetes in brackets) varied in the direction of flow from 1052 (744) ind. $\mathrm{m}^{-2}$ at Stn A to $577 \pm 11(307 \pm 47)$ ind. $\mathrm{m}^{-2}$ at Stn C $[802 \pm 330$ $(523 \pm 415)$ ind. $\mathrm{m}^{-2}$ at $\left.\mathrm{Stn} B\right]$. Bottom photographs revealed a high abundance of polychaete tubes (mainly Oweniidae, Myriochele sp.), which showed an alignment to the direction of flow (Fig. 3). Ophiurids (Ophiocten sp.) as epifaunal organisms were present on each photograph. The sediment consisted of silty clay $(70 \%$ wt $\leq 6.3 \mu \mathrm{m}, 5 \%$ wt $\geq 63 \mu \mathrm{m}$; Blaume 1992).

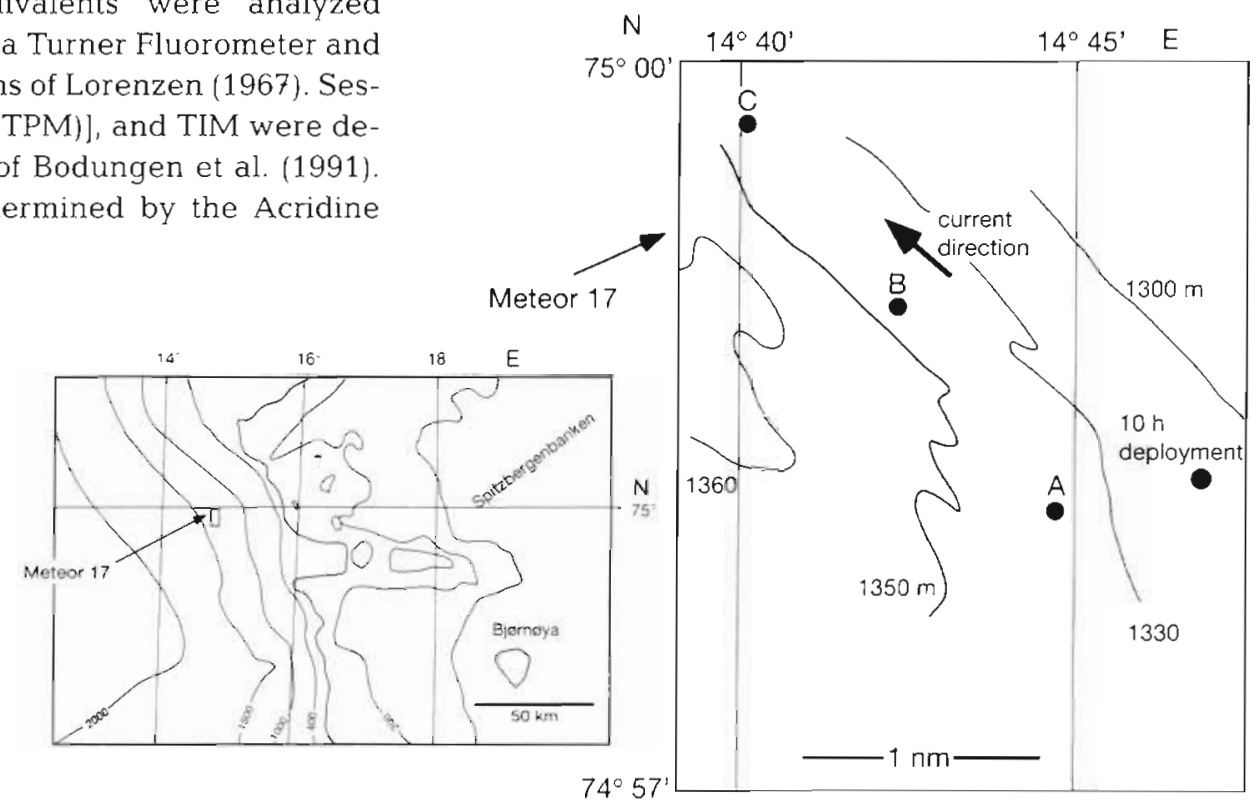

Fig. 1. Location of experimental stations on the Barents Sea continental margin 


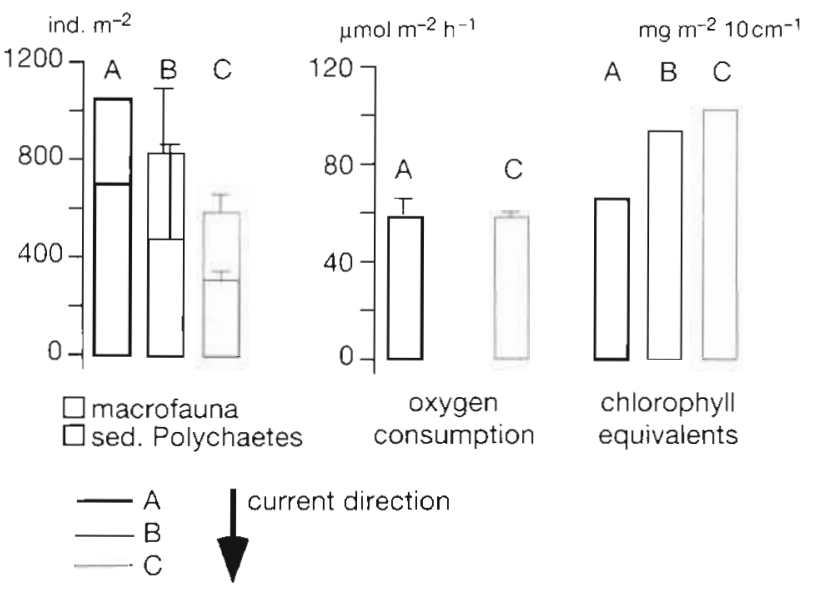

Fig. 2. Profiles of macrofaunal abundance, oxygen consumption and chlorophyll equivalents (integrated over the top $10 \mathrm{~cm}$ layer) in the sediments (sed.) at the experimental stations (Stns A, B and C)

\section{Bottom water}

During the experiments ( 3 periods of 15 min during a $24 \mathrm{~h}$ sampling period, 1 constant period of $10 \mathrm{~h}$ ) the direction of bottom flow was northwesterly. The influence of tides changing the flow direction was not detected. Average flow velocity at a height of $20 \mathrm{~cm}$ was $22.5 \mathrm{~cm} \mathrm{~s}^{-1}$ (intake velocity at all sampling tube openings was 20 to $30 \mathrm{~cm} \mathrm{~s}^{-1}$ ) At the 3 stations the particle concentrations in the different levels above the sea floor varied beween the up- and downstream stations (Fig. 4). For both downstream stations concentrations of oxygen, TPM, TIM, POC and bacterial

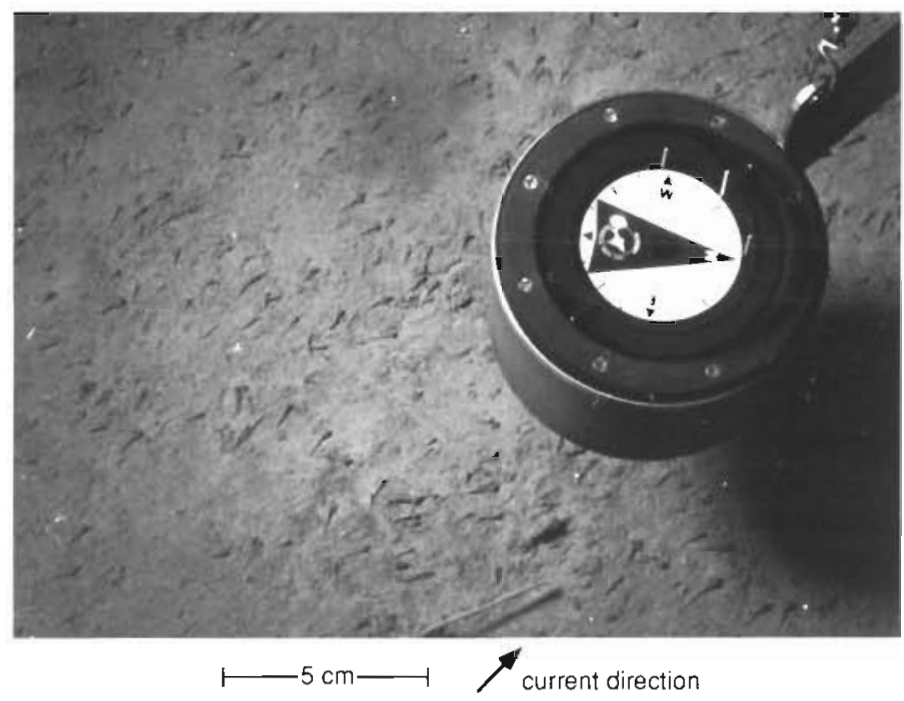

Fig. 3. View of the interface feeder field of Stn A and a Benthos deep-sea compass used to determine flow direction. Bottom photographs revealed high densities of polychaete tubes (mainly Oweniidae, Myriochele sp.) abundance were lower in each of the 10,15, 25 and $40 \mathrm{~cm}$ water layers compared to upstream concentrations ( $p<0.002$, Wilcoxon signed rank), whereas downstream concentrations of chloropyll equivalents were significantly higher $(p<0.01)$.

On average, oxygen concentrations at heights of 10 to $40 \mathrm{~cm}$ above bottom (a.b.) slightly decreased in the direction of flow from $319 \pm 3$ to $313 \pm 5 \mu \mathrm{mol} \mathrm{l} \mathrm{l}^{-1}$. TPM decreased from $1.51 \pm 0.64$ to $1.03 \pm 0.26 \mathrm{mg} \mathrm{l}^{-1}$. TIM from $0.35 \pm 0.18$ to $0.16 \pm 0.08 \mathrm{mg} \mathrm{l}^{-1}$, POC from $80 \pm 20$ to $60.5 \pm 10 \mu \mathrm{g} \mathrm{I}^{-1}$ and bacterial abundance from $3.4 \pm$ 0.5 to $2.3 \pm 1.0 \times 10^{7}$ cells $l^{-1} .35$ to $65 \%$ of the bacteria were particle-attached. The $C: N$ ratio of the organic fraction was $11 \pm 3$. Chlorophyll equivalents increased in the direction of flow from $0.07 \pm 0.02$ to $0.13 \pm$ $0.04 \mathrm{\mu g} \mathrm{l}^{-1}$.

\section{DISCUSSION}

\section{Influence of fauna on the benthic boundary layer}

Research on biodeposition in shallow waters is well documented in the literature. Based on flume experiments in a $20 \mathrm{~m}$ long canal, Asmus \& Asmus (1992) showed that mussel beds on tidal flats can decrease phytoplankton concentrations in near-battom water by $37 \pm 20 \%$. Muschenheim \& Newell (1992) conducted similar experiments and showed that chlorophyll concentrations decrease in the direction of flow above mussel beds at a height of $5 \mathrm{~cm}$ above the sea floor.

The mean abundance of macrofauna showed a decrease from Stns A to $C$, which, however, is not significant within the confidence limits. Nevertheless, the changes in total macrofauna abundance are primarily a result of the changes in the proportion of infaunal polychaetes. It is suggested that the reported depletion in seston concentration is mainly caused by these organisms, acting as 'interface' feeders as reported by Taghon \& Greene (1992). At low flow velocities, feeding is almost exclusively on particles on the sediment surface. At higher velocities, distinctive shifts in feeding behavior are known to occur. Since this feeding type is able to switch from deposit feeding to passive suspension feeding as the flux of suspended particles increases, it is reasonable to conclude that this is the case, for example, for the widespread Myriochele spp. (Fig. 3) (Polychaeta: Oweniidae). The biology of this genus is poorly known; Thistle (1975) and Josefson (1986) suggest that the oweniids are surface deposit feeders. Romero-Wetzel (1989) found green, flocculent material as well as diatoms, benthic foraminiferans and coccolithophorids in guts of 2 

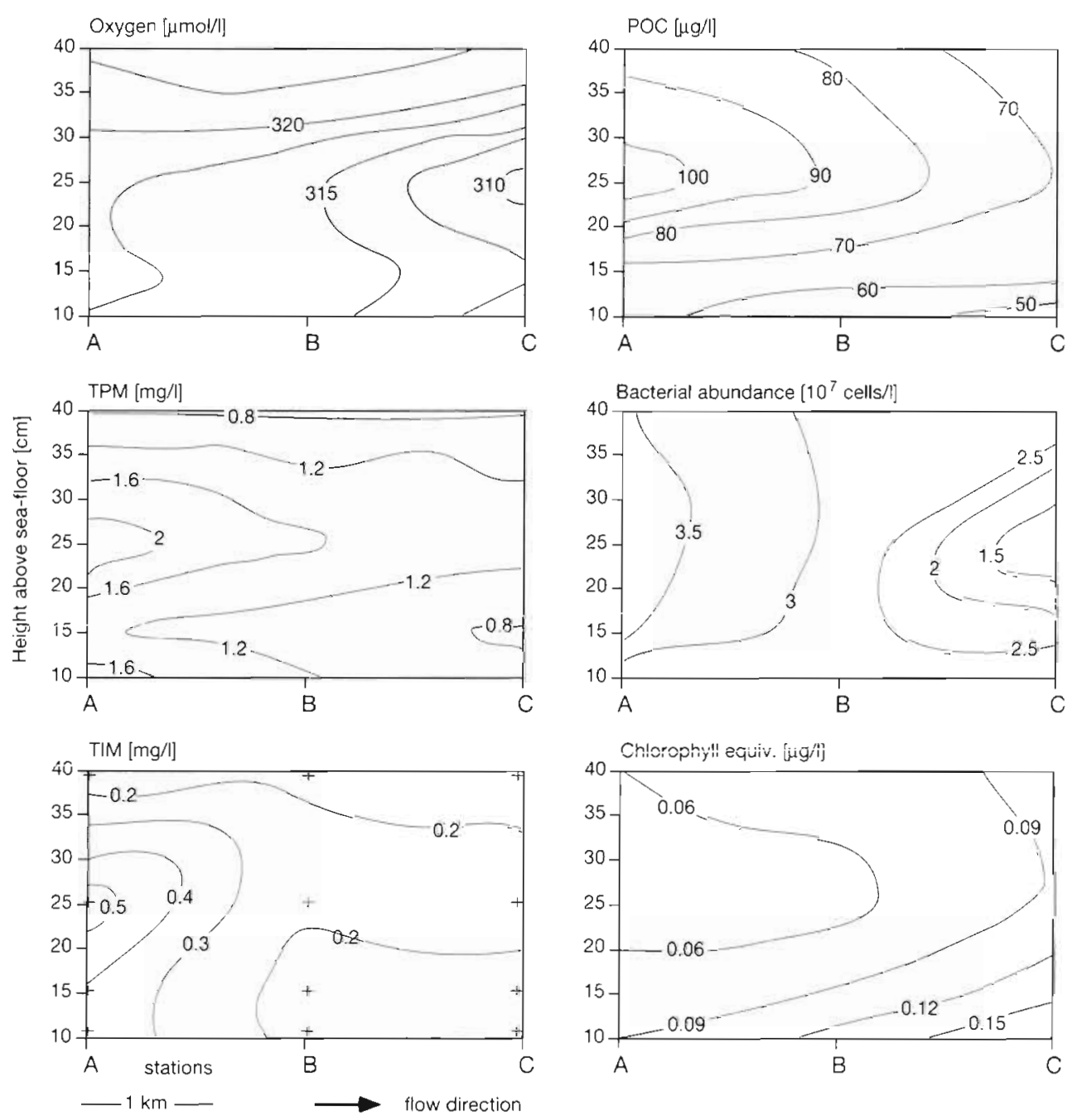

Fig. 4. Concentration profiles of oxygen, total particulate matter (TPM), total inorganic matter (TIM). particulate organic carbon (POC) , bacterial abundance and chlorophyll equivalents in the nearbottom water of the experimental stations (Stns A, B and C)

Myriochele species from the Vøring-Plateau. Because of their mobility, the significance of ophiurids cannot be exactly estimated from box core samples, but they are present in each sample at densities of 12 to 39 ind. $\mathrm{m}^{-2}$. An analysis by Pearson \& Gage (1984) of the gut contents of Ophiocten gracilis from Rockall Trough indicated microphagous feeding. In addition, these authors suggested that deep-sea ophiurids - as well as shallow water forms - are trophic generalists lacking in dietary specialization. Since these ophiurids belong to the vagile epifauna, they may be attracted by the deposited material and are possibly able to switch to suspension feeding. As the sea floor region at the investigated Barents Sea site is a depo-center with 2 Holocene sediment thicknesses of up to $8 \mathrm{~m}$, there were high levels of sedimentation in addition to the horizontal particle transport. Therefore, this region accomodates marine animals of both feeding types.

In this study no significant correlation between decreasing particle load and a reduction of macro- faunal abundance could be established. A possible explanation for the constant levels of oxygen consumption could be given by the abundance of bacteria and meiofauna, which are the dominant consumers of the oxygen and which were not analysed. As the biomass of macrofauna was not determined, its contribution to the sediment oxygen consumption cannot be estimated.

In this study distinct differences in the TPM, TIM and oxygen profiles occurred at the stations between 25 and $40 \mathrm{~cm}$ a.b. At $40 \mathrm{~cm}$ a.b. no distinct trend toward diminished concentrations was evident. These data seem to prove that the strongest influence of nearbottom water masses occurs up to a height of 25 to $40 \mathrm{~cm} \mathrm{a.b}$. It is therefore assumed that the border of an 'internal boundary layer' (Middleton \& Southard 1984), i.e. the local boundary layer affected by the changing physical and benthos-influenced bed conditions above the interface feeder field, lay between 25 and $40 \mathrm{~cm}$ above the sea floor. 


\section{Fluxes}

If, for the purposes of quantification, only those water layers sampled up to a height of $25 \mathrm{~cm}$ a.b. are used to calculate average particle concentrations, the decrease in TPM concentrations of up to $41 \%$, TIM of $51 \%$, organic carbon of $23 \%$ and bacterial abundance of $36 \%$ in the direction of flow represent the massive influence of the interface-feeding polychaetes on nearbottom water masses. The increase in chlorophyll concentrations by $85 \%$ in the direction of flow can be explained by the chlorophyll concentrations in sediments which increased in the direction of flow by $56 \%$. It is suggested that phytodetritus had been resuspended from sediments at the 3 stations at the Barents Sea slope by bottom currents with higher particle concentrations close to the sea floor. The observed increase of chlorophyll in the bottom water in the direction of flow would thus be a result of 'heavy' fluffy phytodetritus (Lampitt 1985) resuspended from sediments. After resuspension, this 'heavy' fraction would be redeposited on the sea floor very quickly. Hence, the 'state of the boundary layer' was less important in their dispersion (Thomsen \& Graf 1995), explaining why pulses of pelagic food production are incorporated into the sea floor so rapidly (Graf 1989).

The current was flowing in a northwesterly direction for $24 \mathrm{~h}$. Assuming that there is no major acrosscurrent exchange, then the along-current particle flux can be analysed in terms of a 2-dimensional box as shown in Fig. 5. Water with an average quantity of particles $p_{v}\left(\mathrm{~g} \mathrm{~m}^{-3}\right)$ over a given depth of the layer moves across the interface feeder field at an average speed $u\left(\mathrm{~cm} \mathrm{~s}^{-1}\right)$. Hence the rate of horizontal particle transport, $A\left(\mathrm{~g} \mathrm{~m}^{-2} \mathrm{~s}^{-1}\right)$, is $A=u p_{v}$. Assuming a current velocity of $20 \mathrm{~cm} \mathrm{~s}^{-1}$ over a period of $24 \mathrm{~h}$ above the interface-feeder field and an internal boundary layer of $30 \mathrm{~cm}$ height, the following horizontal particle flux can be estimated: On average, $405 \mathrm{~g} \mathrm{POC}$ and $9072 \mathrm{~g}$
TPM per $0.3 \mathrm{~m}^{2} \mathrm{~d}^{-1}(0.3 \mathrm{~m}$ high, $1 \mathrm{~m}$ wide) were flowing into the station test field (Fig. 5). After $3.7 \mathrm{~km}$, $312 \mathrm{~g} \mathrm{POC}$ and $5184 \mathrm{~g}$ TPM per $0.3 \mathrm{~m}^{2} \mathrm{~d}^{-1}$ left the $3700 \mathrm{~m}$ long test area per $0.3 \mathrm{~m}^{2} \mathrm{~d}^{-1}$. Chlorophyll has not been included in these calculations, since it is resuspended locally and is quickly redeposited. This corresponds to a lateral depositional flux of $25 \mathrm{mg}$ POC and $1050 \mathrm{mg} \mathrm{TPM} \mathrm{m} \mathrm{m}^{-2} \mathrm{~d}^{-1}$. At a short-term deployment located $35 \mathrm{~km}$ from the test field the vertical particle flux at the time of the experiment in the sediment trap at a depth of $100 \mathrm{~m}$ height above sea floor $(2000 \mathrm{~m}$, resuspended flux) was $25 \mathrm{mg}$ POC and $390 \mathrm{mg}$ TPM $\mathrm{m}^{-2} \mathrm{~d}^{-1}$ (Thomsen 1993). If this vertical particle flux is added to the depositional particle flux via lateral advection, a total depositional flux of $50 \mathrm{mg}$ POC and $1440 \mathrm{mg}$ TPM m $\mathrm{m}^{-2} \mathrm{~d}^{-1}$ was calculated. These calculations demonstrate that a lateral particle flux which is 4 orders of magnitude greater than the vertical particle flux can supply benthic organisms with food. In addition to the vertical particle flux, a combined POC and TPM flux [increased by the lateral advection factor (Laf) $\times$ sedimentation (S) of 2 and 3.7] can provide the benthos with sufficient amounts of food. Taking lower or higher current velocities into account, the amount of carbon introduced into the system by means of lateral advection changes accordingly. However, it is not the mass of particles which is relevant but their direct nutritional value. As 35 to $65 \%$ of the bacteria were particle-attached, these bacterial epiflora will be important for marine animals feeding on these particles. The results of this in situ experiment represent a first attempt to investigate the influence of macrofauna on particle flux in bottom water masses under natural testing conditions at continental margins. When including lateral advection, the total depositional flux correspond with the benthic carbon demand of $\approx 33 \mathrm{mg}$ POC $\mathrm{m}^{-2} \mathrm{~d}^{-1}$ (assuming respiratory quotient, $\mathrm{RQ}, \approx 0.85$ ).

Tests of this nature conducted at these water depths will be made to determine the extent and boundaries of
Fig. 5. Simple model of the particle flux over the interface feeder field. POC: particulate organic carbon; TPM: total particulate matter; Laf: lateral advection factor S: sedimentation

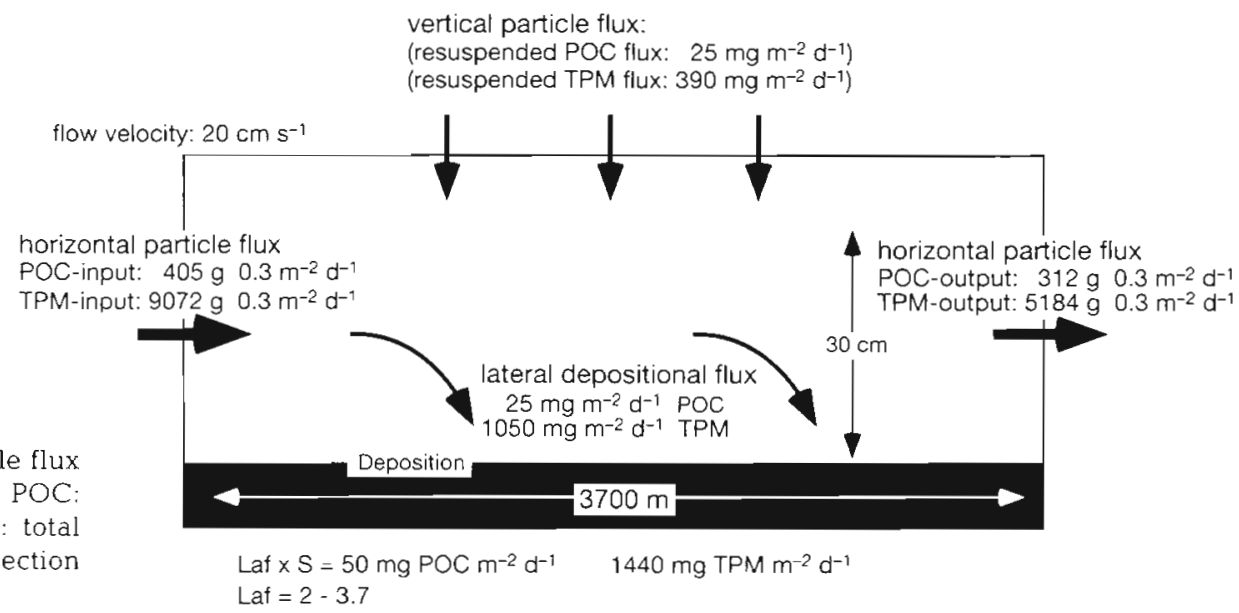

vertical particle flux:

(resuspended POC flux: $25 \mathrm{mg} \mathrm{m}^{-2} \mathrm{~d}^{-1}$ )

列 
certain population patterns using photographic methods. After extensive investigations of characteristic flow patterns in the test area, the input and output quantities of horizontal particle flux at the margins of the test area will be recorded with more than 3 sampling locations in between. The layer of the internal boundary layer affected by the benthos will grow rather slowly requiring a fetch distance of several hundred meters between the sampling locations. This is important to take into account when setting up these experiment locations. Furthermore, such an experiment should ideally also be carried out at a control station with no or little benthic activity to obtain an indication of the number of particles lost due to simply physical factors. An additional video survey of the sea floor along the transect should give information on changes in sediment surface structure and benthic activity. When attempting to balance a benthic carbon demand, one must bear in mind that the question of where these high amounts of carbon transported across a given area area and over a given time originated remains unsolved.

Acknowledgements. The authors thank the crew of RV 'Meteor', especially Captain Bruns, who recovered the Bioprobe system after a $12 \mathrm{~h}$ search when it was lost during a $10 \mathrm{~h}$ deployment. The instrument was dragged with a $10 \mathrm{~km}$ wire with only 1 flowmeter being damaged. We thank 3 reviewers for constructive criticism of the manuscript. This study was supported by the 'Deutsche Forschungsgemeinschaft' This is a publication of GEOMAR and publication no. 239 of the Sonderforschungsbereich 313, Kiel University.

\section{LITERATURE CITED}

Asmus RM., Asmus H (1992) Mussel beds: lirniting or promoting phytoplankton? J exp mar Biol Ecol 148:215-232

Barnett PRO, Watson J, Conelly D (1984) A multiple corer for taking virtually undisturbed samples from, shelf, bathyal and abyssal sediments. Oceanol Acta 7:339-409

Blaume F (1992) Hochakkumulationsgebiete am norwegischen Kontinentalhang. Ber SFB 313 36:1-212

Bodungen Bv, Wunsch M, Fürderer H (1991) Sampling and analysis of suspended and sinking particles in the North Atlantic. Geophys Monogr 63:47-56

Brey T (1986) Formalin and formaldehyde-depot chemicals effects on dry weight and ash free dry weight of two marine bivalve species. Meeresforsch 31:52-57

Carey DA (1983) Particle resuspension in the benthic boundary layer induced by flow around polychaete tubes. Can J Fish Aquat Sci 40:301-308

Eckman JE, Nowell ARM (1984) Boundary skin friction and sediment transport about an animal tube mimic. Sedimentology $31: 851-862$

Graf G (1987) Benthic energy flow during a simulated autumn bloom sedimentation. Mar Ecol Prog Ser 33:23-29

Graf G (1989) Benthic pelagic coupling in a deep-sea benthic community. Nature 341(6241):437-439

Grant J (1983) The relative magnitude of blological and physical sediment reworking in an intertidal community. $\mathrm{J}$ mar Res 41:673-689

Grasshoff K, Ehrhard K, Kremling E (1976) Methods of seawater analysis. Verlag Chemie, Weinheim
Hobbie JE, Daley RJ, Jasper S (1977) Use of Nucleopore filters for counting bacteria by fluorescense microscopy. Appl environ Microbiol 33:1225-1228

Josefson AB (1986) Temporal heterogeneity in deep-water softsediment benthos - an attempt to reveal temporal structure. Estuar coast Shelf Sci 23:147-169

Jumars PA, Gallagher ED (1982) Deep-sea community structure: third place on the benthic proscenium. In: Ernst WG, Morin JG (eds) The environment of the deep-sea. Prentice-Hall, Englewood Cliffs, NJ, p 217-255

Jumars PA, Nowell ARM (1984) Effects of benthos on sediment transport: difficulties with functional grouping. Cont Shelf Res 3:115-130

LaBarbera M (1984) Feeding currents and particle capture mechanisms in suspension feeding animals. Am Zool 24: $71-84$

Lampitt RS (1985) Evidence for seasonal deposition of detritus to the deep-sea floor and its subsequent resuspension Deep Sea Res 32:885-879

Loo LO, Rosenberg R (1989) Bivalve suspension feeding dynamics and benthic-pelagic coupling in an eutrophiCáted marine Way. j exp mar Biol Ecol 130:253-276

Lorenzen CJ (1967) Determination of chlorophyll and phaeopigments: spectrophotometric equations. Limnol Oceanogr 12

Middleton GV, Southard JB (1984) Mechanics of sediment movement. SEPAi shoit course number 3 , 2nd edn. Providence

Miller DC, Bock MJ, Turner EJ (1992) Deposit and suspension feeding in ocillary flows and sediment fluxes. J mar Res 50:489-520

Miller DC, Jumars PA, Nowell ARM (1984) Effects of sediment transport on deposit feeding: scaling arguments. Limnol Oceanogr 29:1202-1217

Muschenheim DK (1987) The role of hydrodynamic sorting of seston in the nutrition of a benthic suspension feeder. Spio setosa (Polychaeta: Spionidae). Biol Oceanogr 4 : $265-288$

Muschenheim DK, Newell CR (1992) Utilization of seston over a mussel bed. Mar Ecol Prog Ser 85:131-136

Nowell ARM, Jumars PA (1984) Flow environments of aquatic benthos. A Rev Ecol Syst 15:303-328

Pearson M, Gage JD (1984) Diets of some deep-sea brittle stars in the Rockall Trough. Mar Biol 82:247-258

Ritzrau W (1990) Methodische Ansätze zur Bearbeitung von bodennahen Trübungszonen. Ber SFB 313 27:3-87

Romero-Wetzel M (1989) Struktur und Bioturbation des Macrobenthos auf dem Voring Plateau. Ber SFB 313 13:1-204

Sternberg RW, Johnson RV, Cacchione DA, Drake DE (1986) An. instrument system for monitoring and sampling suspended sediment in the benthic boundary layer. Mar Geol 71:187-199

Taghon GL, Greene RR (1992) Utilization of deposited and suspended particulate matter by benthic interface' feeders. Limnol Oceanogr 37 (7):1370-1391

Thistle D (1975) Deep-sea harpacticoid copepod diversity maintenance: the role of polychaetes. Mar B1ol 52:371-376

Thomsen C (1993) Verfolgung pelagischer Prozesse mit Hilfe von biochemischen Komponenten am Beispiel der Alkenone. Ber SFB 313 43:1-86

Thomsen L, Graf G. (1995) Characteristics of suspended particulate matter in the benthic boundary layn of the continental margin of the western Barents Sicd. Oceanol Acta 17: in press

Thomsen L, Graf G, Martens V, Steen E (1994) An instrument for sampling water from the benthic boundary layer. Cont Shelf Res 14(7/8):871-882 